\title{
Measuring the performance of privatized banks in Iran
}

\section{Mohammad Taghi Samadi*}

Iran Banking Institute, Tehran, Iran

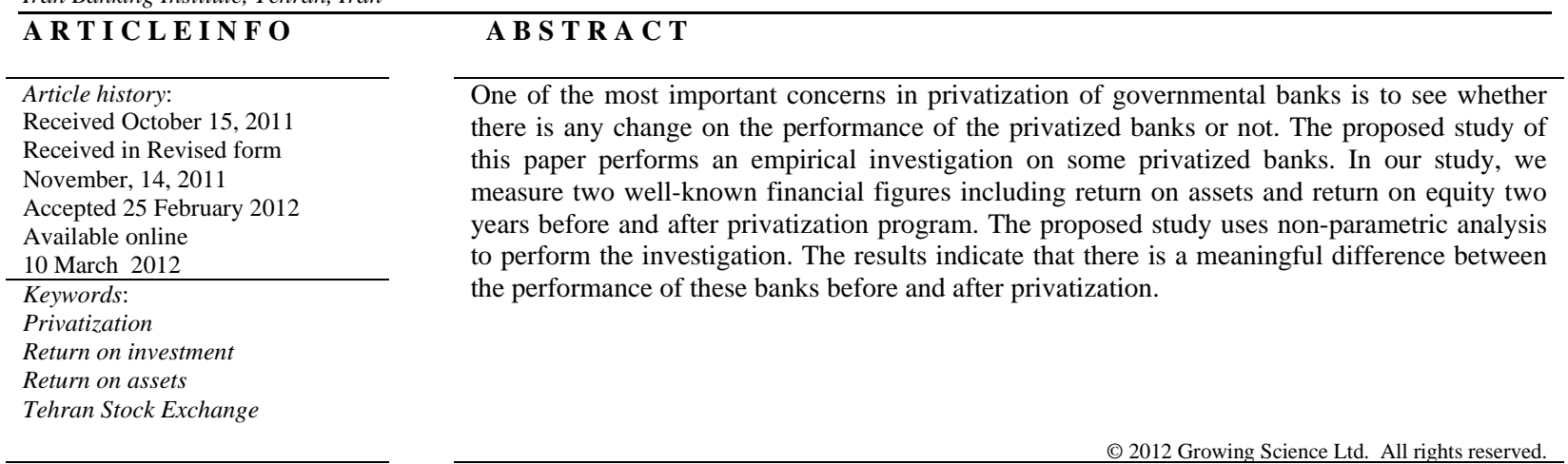

\section{Introduction}

There is no doubt that banking sector plays an important role on economy of all countries. There are normally significant amount of money held by banks and it is necessary to manage the funds, efficiently (Classens \& Peters, 1997; Li, 1998; Grigorian \& Manole, 2002; Sapienza, 2004). Privatization is considered as one of the most important ways to increase the efficiency of governmental banks. There are literally different techniques to measure the performance of the banks such as accounting methods, financial management, monitoring economic figures or combinations of these methods. According to accounting approach, we look at the financial ratios such as net profit, current ratio, quick ratio, inventory turnover, cost of services, earning per share, etc. Financial management is another technique, which looks for other financial figures such as return on assets (ROA) as well as return on equities (ROE). Watching economic figures is the third method, which looks for economic value added, market value added, Tobin's Q, Market-to-book, etc. Finally, the last method is associated with a combination of different techniques such as P/E ratio and market value.

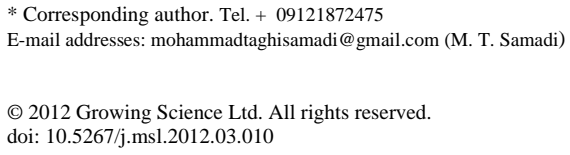


In summary, there are two different categories of performance measurement, which are economical and accounting figures (Demsetz \& Villalonga, 2001; Drakos, 2002; Grigorian \& Manole, 2002).

In banking industry, however, there are other specialized indexes such as CAMELS introduced by Bank of International Settlement (BIS), which was introduced in 1998. This index consists of six factors including capital adequacy, assets quality, management quality, Earnings, Liquidity and Sensitivity. Banker is another index, which is associated with financial times. This index includes the amount of equity, asset value, the ratio equity on total assets, earning before tax, actual profit growth, ratio of earning before tax on total equity, return on assets, ratio of cost of services on revenue, accountability of equity and ratio of unpaid loans.

Beck et al. (2005a) analyzed the various issues including liquidation, federalization, privatization and restructuring the Brazilian state governments faced for the transformation of their state banks under the PROES in the late 1990s. They considered two issues such the factors behind the states choices and the influences of the transformation process on bank performance and efficiency. They reported that states, which were more dependent on federal transfers and the banks, which were already under federal intervention and that established development agencies were more likely to leave control over their banks and its transformation process. They also reported that privatized banks increased their performance, while restructured banks did not.

Nakane and Weintraub (2005) provided some evidences from Brazilian banks' privatization and productivity. They evaluated the influences of these changes in banking total factor productivity. They first calculated measures of bank-level productivity by employing the techniques and investigated the measures to a set of bank characteristics. The main results indicated that state-owned banks were less productive than their private peers, and that privatization had increased productivity. Beck et al. (2005b), in other study, evaluated the influence of privatization on performance in a panel of Nigerian banks from year 1990 to 2001. They reported some evidence of performance improvement in nine privatized banks, which was significant given the inhospitable environment for actual financial intermediation. The results also recommended negative influences of the continuing minority government ownership on the performance of several Nigerian banks.

Berger et al. (2005) performed an investigation on the static, selection, and dynamic influences of domestic, foreign, and state ownership on bank performance. They explained that it is necessary to include indicators of all the relevant governance influences in the same model. They used some historical data from Argentina in the 1990s and reported some important issues on state ownership. According to their results, state-owned banks had poor long-term performance and those undergoing privatization had particularly poor performance beforehand. They reported that privatization could improve banks' performance, significantly. Bonin et al. (2005a) used data from 1996 to 2000 to study the impacts of ownership by a strategic foreign owner, on bank efficiency for eleven transition countries in an unbalanced panel including 225 banks out of 856 observations. They applied stochastic frontier estimation procedures, computed profit, and cost efficiency of both time and country effects, directly. In second-stage regressions, they implemented the efficiency measures along with ROA to investigate the impact of ownership type.

With respect to the influence of ownership, they concluded that privatization by itself was not sufficient to increase bank efficiency as government-owned banks were not appreciably less efficient than domestic private banks. They found that foreign-owned banks were more cost-efficient than other banks and that they also provided better service, in particular if they had a strategic foreign owner. The remaining government-owned banks were less efficient in providing services, which was consistent with the hypothesis that the better banks were privatized first in transition countries. Bonin et al. (2005b) considered the largest banks in six relatively advanced countries, namely, Bulgaria, the Czech Republic, Croatia, Hungary, Poland and Romania to study the influence of bank privatization in transition countries. They used financial statements including income and balance sheet 
characteristics and efficiency figures computed from stochastic frontiers and there were compared across four bank ownership types.

Bonin's results confirmed the hypotheses where foreign-owned banks were most efficient and government-owned banks were least efficient. Besides, the importance of absorbing a strategic foreign owner in the privatization process was also confirmed. Nevertheless, they found that domestic banks had a local advantage in pursuing fee-for-service business. They also showed that both the method and the timing of privatization play important role on performance.

Boubakri et al. (2005) investigated privatization and bank performance in developing countries. They studied the postprivatization performance of 81 banks out of 22 developing countries. The results indicated that on average, banks chosen for privatization had a lower economic efficiency, and a lower solvency than banks, which were under government ownership.

They also reported that in the postprivatization period, profitability edged up but, depending on the type of ownership, efficiency, risk exposure and capitalization could be worsen or improved. They reported that over time, privatization resulted substantial improvements in economic efficiency and credit risk exposure and believed that newly privatized banks, which were controlled by local industrial groups become more exposed to credit risk and interest rate risk after privatization.

George et al. (2005) summarized the results from the papers in the special issue of the Journal of Banking and Finance on bank privatization and concluded that although bank privatization usually improves bank efficiency, gains were bigger when the government fully relinquishes control, when banks' shares were sold to strategic investors, when foreign banks were permitted to take part in the privatization process and when the government did not restrict competition.

The proposed study of this paper considers the impact of privatization in banking sector. The organization of this paper first presents details of our survey in section 2 and presents the results in section 3. Finally, concluding remarks are given in the last section.

\section{Proposed model}

In this survey, we study 18 active Iranian banks and use two key statistics, ROA and ROE, in two periods, from 2004 to 2010. There are three hypotheses associated with the proposed study of this paper, which are as follows,

First hypothesis: The performances of governmental banks are improved compared with other banks.

Second hypothesis: The privatized banks have better performance compared with their present average performance.

Third hypothesis: The performances of present governmental banks are lower than average privatized ones.

Table 1 shows the average and standard deviation of two financial factors of ROA and ROE. As we can observe from the numbers in Table 2, the average ROE and ROA are $31.5 \%$ and 2.48, respectively. It seems that there is a relatively large standard deviation of ROE for private banks.

The average ROE and ROA for the same period were 12.5 and .72 respectively, which are lower than private banks. In addition, they present lower standard deviation compared with private banks. The governmental banks had much lower average of ROE and ROA compared with other two banking sectors. It is worth to note the performances of these banks in terms of ownership states and Table 2 shows the information. In our study, we compare the relative performances of nine banks. 
Table 1

ROA and ROE for banks

\begin{tabular}{|c|c|c|c|c|c|c|c|}
\hline Bank & Variable & Mean & Standard deviation & Bank & Variable & Mean & Standard deviation \\
\hline \multirow{2}{*}{ Karafarin } & ROE & 40.37 & 14.41 & Sepah & ROE & 2.99 & 4.72 \\
\hline & ROA & 2.98 & 1.41 & & ROA & 0.27 & 0.55 \\
\hline \multirow{2}{*}{ Parsian } & $\mathrm{ROE}$ & 33.83 & 8.56 & Maskan & ROE & 22.00 & 11.69 \\
\hline & ROA & 2.18 & 0.66 & & ROA & 1.60 & 0.85 \\
\hline \multirow{2}{*}{ Eghtesade Novin } & ROE & 32.90 & 6.91 & Refah & ROE & 21.05 & 27.59 \\
\hline & ROA & 1.92 & 0.89 & & ROA & 0.60 & 0.73 \\
\hline \multirow{2}{*}{ Pasargad } & ROE & 19.14 & 8.62 & Keshavarzi & $\mathrm{ROE}$ & 6.86 & 6.22 \\
\hline & ROA & 3.04 & 0.50 & & ROA & 0.48 & 0.48 \\
\hline \multirow{2}{*}{ Saman } & $\mathrm{ROE}$ & 27.69 & 6.55 & Sanaat Maadan & $\mathrm{ROE}$ & 8.45 & 10.24 \\
\hline & ROA & 2.01 & 1.17 & & ROA & 2.69 & 2.75 \\
\hline \multirow{2}{*}{ Mellat } & ROE & 10.99 & 4.99 & Sarmayeh & $\mathrm{ROE}$ & 10.59 & 4.99 \\
\hline & ROA & 0.51 & 0.18 & & ROA & 3.62 & 2.42 \\
\hline \multirow{2}{*}{ Tejarat } & $\mathrm{ROE}$ & 13.57 & 4.80 & Sina & $\mathrm{ROE}$ & 46.18 & 35.72 \\
\hline & ROA & 0.76 & 0.27 & & ROA & 1.75 & 1.11 \\
\hline \multirow{2}{*}{ Saderat } & $\mathrm{ROE}$ & 12.90 & 8.10 & Developing export & $\mathrm{ROE}$ & 7.26 & 4.10 \\
\hline & ROA & 0.87 & 0.53 & & ROA & 2.50 & 1.03 \\
\hline \multirow{2}{*}{ Melli } & $\mathrm{ROE}$ & 2.96 & 1.84 & Post & $\mathrm{ROE}$ & 8.45 & 10.24 \\
\hline & ROA & 0.18 & 0.08 & & ROA & 2.69 & 2.75 \\
\hline
\end{tabular}

Table 2

Ownership status

\begin{tabular}{cccc}
\hline Ownership & Variable & Mean & Standard deviation \\
\hline \multirow{2}{*}{ Private } & ROE & 31.5133 & 18.74194 \\
& ROA & 2.4889 & 1.30939 \\
\hline \multirow{2}{*}{ Privatized bank } & ROE & 12.4919 & 5.94841 \\
& ROA & .7176 & .38181 \\
\hline \multirow{2}{*}{ Governmental } & ROE & 9.7337 & 13.65526 \\
& ROA & 1.0937 & 1.50805 \\
\hline
\end{tabular}

\section{The results}

In our survey, we compare the relative performances of the banks two years before and after the privatization performed. Since there are limited numbers of observations, we use nonparametric test called Kruskal-Wallis and the level of significance is assumed to be 0.05 . Table 4 shows details of our test for the first hypothesis, which confirms that privatized banks had better performance than governmental ones.

Table 3

Average ranks of banks in terms of ROE and ROA

\begin{tabular}{ccccc}
\hline Period & Ownership & Numbers & Average ROE rank & Average ROA rank \\
\hline \multirow{2}{*}{$\begin{array}{c}\text { Two years before } \\
\text { and after }\end{array}$} & Private & 17 & 35.94 & 34.09 \\
& Privatized & 9 & 20.89 & 14.78 \\
& Governmental & 22 & 17.14 & 21.07 \\
\hline \multirow{3}{*}{ Two years before } & Private & 14 & 27.14 & 27.43 \\
& Privatized & 6 & 16.17 & 13.17 \\
& Governmental & 16 & 11.81 & 12.69 \\
\hline \multirow{2}{*}{ Two years after } & Private & 14 & 27.43 & 27.50 \\
& Privatized & 6 & 18.83 & 14.17 \\
& Governmental & 16 & 10.56 & 12.25 \\
\hline
\end{tabular}

Table 5 shows the average performances of the private banks two years before and after the privatization using Mann-Whitney test. As we can observe from the results, the average ROA and ROE of privatized banks after privatization are higher than other groups of banks. 
Table 4

Kruskal-Wallis test for the first hypothesis

\begin{tabular}{cccc}
\hline Period & Test & ROA & ROE \\
\hline \multirow{2}{*}{ Two years before and after } & Chi-Square & 13.638 & 18.040 \\
& $\mathrm{df}$ & 2 & 2 \\
& Asymp. Sig. & .001 & .000 \\
\hline \multirow{2}{*}{ Two years before } & Chi-Square & 16.466 & 16.162 \\
& $\mathrm{df}$ & 2 & 2 \\
& Asymp. Sig. & .000 & .000 \\
\hline \multirow{2}{*}{ Two years after } & Chi-Square & 16.862 & 19.145 \\
& $\mathrm{df}$ & 2 & 2 \\
& Asymp. Sig. & .000 & .000 \\
\hline
\end{tabular}

Table 5

The results of Mann-Whitney test of Mean of ROA and ROE before and after privatization

\begin{tabular}{ccccc}
\hline Period & Ownership & numbers & Mean ROE & Mean ROA \\
\hline \multirow{2}{*}{ Two years before } & Private & 14 & 14.93 & 14.29 \\
privatization & Privatized & 6 & 4.50 & 4.17 \\
& Governmental & 16 & 15.31 & 15.59 \\
\hline \multirow{2}{*}{ Two years after } & Private & 14 & 14.07 & 14.71 \\
privatization & Privatized & 6 & 8.50 & 8.83 \\
& Governmental & 16 & 17.69 & 17.41 \\
\hline
\end{tabular}

The results of Mann-Whitney test when the level of significance is five percent are summarized in Table 6. The results show that ROE and ROA among three groups of banks are different before and after privatization happen. Therefore, the second hypothesis, which indicates that the performances of governmental banks are improved after privatization is confirmed for ROE and ROA when the level of significance are 90 and 95 percents, respectively.

Table 6

The results of statistical test

\begin{tabular}{cccc}
\hline Ownership & Test & ROA & ROE \\
\hline \multirow{3}{*}{ Private } & Mann-Whitney U & 95.000 & 92.000 \\
& Wilcoxon W & 200.000 & 197.000 \\
& Z &. .138 & -.276 \\
& Asymp. Sig. (2-tailed) & .890 & .783 \\
\hline \multirow{4}{*}{ Privatized } & Mann-Whitney U & 4.000 & 6.000 \\
& Wilcoxon W & 25.000 & 27.000 \\
& Z & -2.246 & -1.922 \\
& Asymp. Sig. (2-tailed) & .025 & .055 \\
\hline \multirow{3}{*}{ Governmental } & Mann-Whitney U & 113.500 & 109.000 \\
& Wilcoxon W & 249.500 & 245.000 \\
& Z & -.547 & -.716 \\
& Asymp. Sig. (2-tailed) & .585 & .474 \\
\hline
\end{tabular}

Table 7

The average ROA and ROE two years before and after privatization

\begin{tabular}{ccccc}
\hline Period & Ownership & No. & Mean ROE & Mean ROA \\
\hline \multirow{3}{*}{ Two years before } & Private & 14 & 27.0736 & 2.5450 \\
& Privatized & 6 & 8.6783 & .5050 \\
& Governmental & 8 & 4.3088 & -.0313 \\
\hline \multirow{3}{*}{ Two years after } & Private & 14 & 25.6550 & 2.2293 \\
& Privatized & 6 & 16.0150 & 1.0233 \\
& Governmental & 8 & 15.4813 & .5525 \\
\hline
\end{tabular}

To test the second and third hypothesis, we perform nonparametric test and the results are summarized in Table 7 and Table 8. As we can observe, there is a meaningful difference between the 
mean ROA and ROE for privatized banks before and after two years. In other words, privatized banks almost doubled their performance two years after the privatization happened.

Table 8

Statistical tests on privatized banks from 2002 to 2008 and governmental banks from 2009 to 2010

\begin{tabular}{llcrcccc}
\hline & Ownership & Mean(2004-2008) & t-student & difference & df & Mean (2009-2010) & p-value \\
\hline ROE & Privatized & 12.4919 & -2.714 & -3.523 & 20 & 16.015 & 0.013 \\
\hline ROA & Privatized & .7176 & -3.665 & -0.030 & 20 & 1.023 & 0.002 \\
\hline ROE & Governmental & 9.7337 & -3.38 & -6.28 & 53 & 16.015 & 0.001 \\
\hline ROA & Governmental & 1.0937 & 0.345 & 0.0732 & 53 & 1.023 & 0.732 \\
\hline
\end{tabular}

Based on the results of Table 8, we can confirm the next hypothesis, which specifies that the performances of previous privatized banks are lower than their present circumstance. Finally, we can confirm the last hypothesis that the performances of governmental banks are lower than their privatized ones.

\section{Conclusion}

In this paper, we have presented an empirical results on the performances of some governmental banks whose shares have been sold to private sectors. The study was performed from year 2002 to year 2008. We have compared two ratios of return on equity and return on assets for these banks and compared these two ratios two years before and after privatization process. The results of our study have indicated that the banking sector could improve its performance by privatizing their ownerships. In fact, many privatized banks increase their equities through increasing the number of shares and restructuring their business units after their shares were traded on Tehran Stock Exchange.

\section{References}

Beck, T., Crivelli, J.M., \& Summer hill, W. (2005a). State bank transformation in Brazil - Choices and consequences. Journal of Banking and Finance, 29, 2223-2257.

Beck, T., Cull, R., \& Jerome, A. (2005b). Bank privatization and performance: Empirical evidence from Nigeria. Journal of Banking and Finance, 29, 2355-2379.

Berger, A., Clarke, G.R.G., Cull, R., Klapper, L., \& Udell, G.F. (2005). Corporate governance and bank performance: A joint analysis of the static, selection, and dynamic effects of domestic, foreign, and state ownership. Journal of Banking and Finance, 29, 2179-2221.

Bonin, J.P., Hasan, I., \& Wachtel, P. (2005a). Bank performance, efficiency and ownership in transition countries. Journal of Banking and Finance, 29, 31-53.

Bonin, J.P., Hasan, I., \& Wachtel, P. (2005b). Privatization matters: Bank efficiency in transition countries. Journal of Banking and Finance, 29, 2155-2178.

Boubakri, N., Cosset, J., Fischer, K., \& Guedhami, O. (2005). Privatization and bank performance in developing countries. Journal of Banking and Finance, 29, 2015-2041.

Clarke, G.R.G., Cull, R., \& Shirley, M.M. (2005). Bank privatization in developing countries: A summary of lessons and findings. Journal of Banking and Finance, 29, 1905-1930.

Classens, S., \& Peters, R.K. (1997). State enterprise performance and soft budget constraints. Economics of Transition, 5, 305-322.

Demsetz, H., \& Villalonga, B. (2001). Ownership Structure and Corporate Performance. Journal of Corporate Finance 2001, 7, 209-233.

Drakos, K. (2002). The efficiency of the banking sector in Central and Eastern Europe. Russian and East European Finance and Trade, 38, 31-43.

Grigorian, D., \& Manole, V. (2002). Determinants of commercial bank performance in transition: An application of data envelopment analysis. World Bank Policy Research Working Paper 2850, June.

Li, Y. (1998). The economic prospect for 1999-2000. Speech at Peking University.

Nakane, M., \& Weintraub, D. (2005). Bank privatization and productivity: Evidence from Brazil. Journal of Banking and Finance, 29, 2259-2289.

Sapienza, P. (2004). The effects of government ownership on bank lending. Journal of Financial Economics, 72, 357-385. 